\title{
INCIDENCE OF SPINAL CANCER IN A TERTIARY CARE HOSPITAL IN MEXICO
}

\author{
INCIDÊNCIA DE CÂNCER DA COLUNA VERTEBRAL EM UM HOSPITAL DE TERCEIRO NÍVEL \\ DE ATENÇÃO NO MÉXICO
}

\section{INCIDENCIA DE CÁNCER DE COLUMNA VERTEBRAL EN UN HOSPITAL DE TERCER NIVEL DE ATENCIÓN EN MÉXICO}

\author{
Álvaro José Montiel-Jarouín, ${ }^{1}$ Ivet Etchegaray-Morales, ${ }^{2}$ María del Socorro Romero-Figueroa, ${ }^{3}$ Elleen Amaro-Balderas, ${ }^{1}$ José Juan Castillo-Pérez, ${ }^{3}$ \\ luis Carlos Blanco-Ochoa, ${ }^{1}$ Yony Osorio-Garcia, ${ }^{4}$ Eduardo Vázouez-Cruz, ${ }^{5}$ Rodolfo Gregorio Barragán-Hervella \\ 1. Instituto Mexicano del Seguro Social, High Specialty Medical Unit of the Hospital de Especialidades de Puebla, Investigation Division, Puebla, Mexico. \\ 2. Universidad Autónoma de Puebla, Facultad de Medicina de la Benemérita, Puebla, Mexico. \\ 3. Instituto Mexicano del Seguro Social, Health Investigation Coordination, Puebla, Mexico. \\ 4. Universidade de São Paulo, Faculdade de Medicina de Ribeirão Preto, Hospital das Clínicas, Ribeirão Preto, SP, Brazil. \\ 5. Instituto Mexicano del Seguro Social, Puebla State Delegation, Mexico.
}

\begin{abstract}
Objective: To determine the incidence of primary malignant bone tumors of the spine in a High Specialty Orthopedics and Traumatology Medical Unit. Methods: Review study. The study included patients receiving benefits from the Mexican Social Security Institute of all ages and both sexes with malignant spinal bone tumors during the period from 2010 to 2017. The descriptive statistics used were central tendency measures and dispersion in the SPSS v. 22 program from IBM. The results are presented in tables and figures. Results: There were 107 patients, 56 (52.34\%) men, 51 (47.66\%) women with a mean age of $59.75 \pm 10.76$ years (minimum 35, maximum 88). There were 46,840 hospital discharges during the period, for an annual average of 5,855 and a monthly average of 487.91 . Of the 107 study cases, 78 (72.89\%) were in the lumbosacral, 15 (14.01\%) in the cervical, and 14 (13.08\%) in the thoracic region. The incidence for the period was 1.9/1000 discharges, 1.38in 2010 increasing to 2.32 in 2017. Conclusions: The behavior of primary malignant spinal tumors has increased its presentation from 2010 to 2017. Level of evidence III; Non-analytical, descriptive study.
\end{abstract}

Keywords: Incidence; Frequency; Mexico; Spine; Cancer.

\section{RESUMO}

Objetivo: Conhecer a incidência de tumores ósseos malignos primários da coluna vertebral em uma unidade médica de alta especialidade médica em Ortopedia e Traumatologia. Métodos: Estudo de revisão. O período do estudo incluiu os anos de 2010 a 2017 incluindo pacientes com tumores ósseos malignos da coluna vertebral, de todas as idades e ambos os sexos e usuários do IMSS (Instituto Mexicano de Seguridade Social). Foram utilizadas medidas estatísticas descritivas de tendência central e de dispersão no programa SPSS v. 22 IBM. Os resultados são apresentados em tabelas e gráficos. Resultados: O estudo incluiu 107 pacientes, 56 (52,34\%) homens e 51 mulheres (47,66\%); idade média 59,75 + 10,76 anos (mínima 35, máxima 88). As altas hospitalares durante o período foram 46840, média anual de 5855 e média mensal de 487,91; dos tumores malignos 78 (72,89\%) foram na região lombossacra, 15 (14,01\%) na região cervical e 14 (13,08\%) na região torácica. A incidência do período foi de 1,9/1000 altas, 1,38 em 2010, aumentando para 2,32 em 2017. Conclusões: 0 comportamento dos tumores malignos primários da coluna vertebral tem aumentado desde 2010 a 2017. Nível de evidência III; Estudo analítico-descritivo.

Descritores: Incidência; Frequência; México; Coluna Vertebral; Câncer.

\section{RESUMEN}

Objetivo: Conocer la incidencia de tumores óseos malignos primarios de columna vertebral en una Unidad Médica de Alta Especialidad en Ortopedia y Traumatología. Métodos: Estudio de revisión. El período de estudio comprendió los años 2010 a 2017 , incluyendo a pacientes con tumores óseos malignos de columna vertebral, de todas las edades y ambos sexos, y usuarios del IMSS (Instituto Mexicano del Seguro Social). Fueron utilizadas medidas estadísticas descriptivas de tendencia central y de dispersión en el programa SPSS v. 22 de IBM. Los resultados son presentados en tablas y gráficos. Resultados: El estudio incluyó a 107 pacientes, 56 hombres (52,34\%), y 51 mujeres (47,66\%); edad promedio 59,75 + 10,76 años (mínima 35, máxima 88). Las altas hospitalarias durante el período fueron 46840, promedio anual de 5855 y promedio mensual de 487,91; de los tumores malignos, 78 (72,89\%) casos en la región lumbosacra, 15 (14,01\%) en la región cervical y 14 (13,08 \%) en la región torácica. La incidencia del período fue 1,9/1000 altas, 1,38 en 2010, aumentando para 2,32 en 2017. Conclusiones: El comportamiento de los tumores malignos primarios de columna vertebral ha aumentado desde 2010 a 2017. Nivel de evidencia III; Estudio analítico-descriptivo.

Descriptores: Incidencia; Frecuencia; Tumor; México; Columna Vertebral; Cáncer. 


\section{INTRODUCTION}

Spinal tumors are rare lesions, ${ }^{1-5}$ but these tumors are the third leading cause of death from cancer in patients under 20 years of age..$^{6,7}$

In Cuba, from 1990 to 1992 the incidence of these tumors was $1.2 / 100,000$ inhabitants. ${ }^{1,2}$ In 2015, in the United States the incidence was much higher (2.9/100,000 inhabitants for all osteoarticular tumors). ${ }^{1,6,8}$

Because of technological advances, the incidence of malignant spinal tumors has increased; ${ }^{3}$ metastatic tumors are the most common in elderly patients and osteosarcoma in patients under 40 years of age. 1,4-6,7

The development of malignant tumors in the spine occurs mainly in the anterior region of the vertebral body because it is the most vascularized part of the spine. 1,8,9 $^{-1}$

Some authors report the frequency of spinal involvement by site as $70.3 \%$ for the lumbosacral region, $21.6 \%$ for the thoracic region, and $8.1 \%$ for the cervical region, ${ }^{1,10-12}$ while in other series the thoracic spine is reported to be the region with the most cases of malignant tumors. , $13-16^{-10}$

Because the incidence of these tumors in southern Mexico is unknown, we decided to conduct this study in which its incidence from 2010 to 2017 is presented.

\section{METHODS}

This was a cross-sectional review study, conducted at the High Specialty Medical Unit of the Hospital de Traumatología y Ortopedia de Puebla (UMAE HTOP), a referral center for patients receiving benefits from the Mexican Social Security Institute in the Southern Region of Mexico, during the years 2010 to 2017. The medical records of all patients with malignant primary spinal bone tumors, referred to the medical units of the Mexican Social Security Institute in the Southeast of the Republic of Mexico for the first time during the study period, were reviewed. Patients of both sexes and of all ages with complete clinical records and a diagnosis of primary malignant spinal tumor according to the International Classification of Diseases (ICD 10) were included. In all cases, the diagnoses were confirmed by histopathological studies. The age and sex of the patients, as well as the anatomical site of the lesion and the annual incidence as a percentage of total hospital discharges, were analyzed. The data were obtained from the IMSS Operational Medical Information System (SIMO) and the analysis units were set up for each file. The statistics used were descriptive, measures of central tendency and dispersion, frequencies and rates of hospital discharges during the period. The research protocol was approved by Institutional Review Board No. 2015 of the Medical Unit. The anonymity of participating patient data was always maintained. Because this study was a review of medical records no Informed Consent Form was required.

\section{RESULTS}

We identified 107 new cases of malignant primary spinal bone tumors, 56 (52.34\%) of whom were men and 51 (47.66\%) women. The average age was $59.75 \pm 10.76$ years, with a minimum age of 35 and a maximum age of $8 \overline{8}$.

There were a total of 46,830 hospital discharges during the study period with a yearly average of 5,855 and a monthly average of 487.91 .

Most of the malignant tumors $(72.89 \%)$ were in the lumbosacral segment, followed by the cervical region, and finally by the thoracic region. The distribution of the tumors by region and sex is shown in Table 1.

The overall incidence (for the period) was 1.99/1000 discharges, increasing from 1.38 in 2010 to 2.32 in 2017 . The details are shown in Figure 1.

\section{DISCUSSION}

Cancer is a global health problem. In many both industrialized and developing countries $25 \%$ of deaths are attributed to cancer. ${ }^{16-17}$ In Latin America, cancer is the third leading cause of death.
Table 1. Annual incidence of malignant primary spinal bone tumors by origin of the lesion.

\begin{tabular}{c|c|c|c}
\hline \multirow{2}{*}{ Period } & \multirow{2}{*}{ Discharges/year } & \multicolumn{2}{|c}{ Total cases } \\
\cline { 3 - 4 } & & $\mathbf{n}$ & Rate $^{*}$ \\
\hline 2010 & 6,501 & 9 & 1.38 \\
\hline 2011 & 6,394 & 10 & 1.56 \\
\hline 2012 & 6,464 & 13 & 2.01 \\
\hline 2013 & 6,215 & 12 & 1.93 \\
\hline 2014 & 6,422 & 14 & 2.18 \\
\hline 2015 & 6,684 & 15 & 2.24 \\
\hline 2016 & 7,350 & 17 & 2.31 \\
\hline 2017 & 7,311 & 17 & 2.32 \\
\hline Period & 46,840 & 107 & 1.99 \\
\hline
\end{tabular}

Abbreviations: * =rate per 1000 hospital discharges. Source: Operational Medical Information System (SIMO) of the High Medical Specialty Unit of the Hospital de Traumatología y Ortopedia de Puebla of the Mexican Social Security Institute.

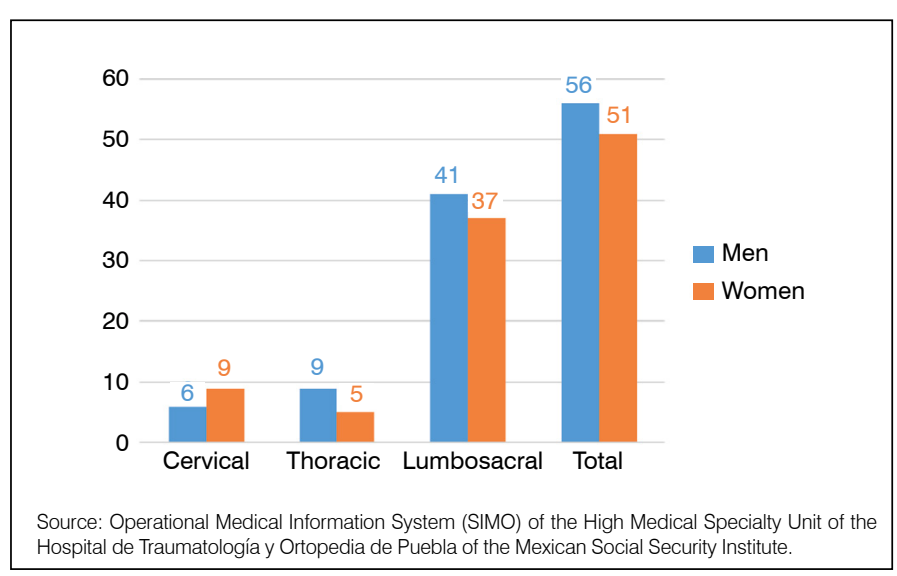

Figure 1. Shows the tumor location by anatomical region by the sex of the patients.

In Mexico, there are few records on spine cancer. In 2009, 65 cases were recorded per 100,000 inhabitants. ${ }^{18}$ That is why we decided to conduct this study in which we present the incidence of malignant primary spinal tumors during the period from 2010 to 2017.

As regards the age of presentation of these tumors, an average of 59.75 years of age was observed. Gómez-Villanueva et al. ${ }^{18}$ reported an average age of 57 years, although other series have reported earlier ages of presentation for these malignant tumors. ${ }^{18}$ A Mexican case series reported a similar age of presentation for these tumors (53.3 years). ${ }^{1,18}$

Kelley et al. reported that these lesions account for 4 to $5 \%$ of all primary bone lesions. ${ }^{19}$ According to the National Cancer Institute [Instituto Nacional de Cancerología (INCAN)], from 2000 to 2004 the frequency of all bone tumors was $1.6 \%$ of all neoplasias in Mexico. ${ }^{20}$

In this study, the incidence of malignant spinal tumors during the period was 1.99 per 1000 hospital discharges. It is notable that the incidence of these tumors has risen from 2010 to 2017, increasing from $1.38 / 1000$ to $2.32 / 1000$.

The percentage of involvement from these lesions was higher in men than in women in this study, at $52.34 \%$ vs. $47.66 \%$. Kelly et al. report similar data, but other authors report equal frequencies for men and women. $9,11,17-21$

Cervical and dorsal locations were less frequent, with 15 and 14 cases, respectively, and the 78 remaining cases were in the lumbosacral region. This data differs from that reported by Kelly et al., who reported a higher frequency of these tumors in the dorsal region as compared to the other regions. ${ }^{19}$ Regarding this data, the fact that only primary lesions are being considered in this study and that metastatic lesions occur primarily in the lumbosacral segment because it is the most vascularized segment must be taken into account. ${ }^{20-22}$

In terms of involvement by segment, we were not able to establish any points of comparison in the literature for a population like ours.

The incidence of primary malignant spinal tumors found in this 
study serves as a knowledge base for behavior and is consistent with that reported in other developing countries, but it is lower than reported in developed countries.

We believe that public health authorities must take preventative actions since early diagnosis can improve the prognosis in these patients. Additionally, given that the incidence considers new cases over a period of time and that sometimes it is not possible to identify all of these, there may have been a minor variation in the real rate presented in this study.

\section{CONCLUSION}

The incidence of malignant primary spinal bone tumors during the period from 2010 to 2017 increased significantly.

All authors declare no potential conflict of interest related to this article.

CONTRIBUTION OF THE AUTHORS: Each author made significant individual contributions to this manuscript. AJMJ, EAB, MSRF, and LCBO participated in the concept and design of the study. JJCP, EVC, IEM, YOG, and RGBH contributed to the literature review. AJMJ, MSRF, and IEM conducted the statistical analysis. All authors reviewed and approved the final version of the article.

\section{REFERENCES}

1. Bitar-Alatorre WE. Tumores y la columna vertebral. Orthotips. 2013:9(3):192-210.

2. Larragoiti-Ramirez CA. Incidencia de tumores óseos en columna vertebral. Revisión de casos en el Hospital de Traumatología y Ortopedia de Puebla del Instituto Mexicano del Seguro Social Enero 2010 a diciembre 2013 [Tesis]. Puebla, Benemérita Universidad Autónoma de Puebla. Facultad de Medicina; 2013.

3. Lobo Antunes J. Tumors of the vertebral column. Neurocir. 1991;2(3):198-201.

4. United States. National Cancer Institute. Cancer Statistics 2000 Incidence Report (consultado en https://www.reportlinker.com/market-report/Cancer/514442/Cancer?utm source=adwords4\&utm_medium =cpc\&utm_campaign=Pharmaceuticals\&utm_ adgroup =Cancer_Reports \& gclid=EAIalOobChMIroXMzKef5gIV XR-tBh1fjApMEAAYASAÄEgKAUPD BwE. Disponible en http://www.seer.cancer.gov.

5. Rodríguez-Salva A, Martín-García A. El Registro Nacional de Cáncer de Cuba. Procedimientos y Resultados. Rev Bras Cancerol. 2001:47(2):171-7.

6. National Cancer Institute. Cáncer de hueso (consultado 25 Nov. 2013). Disponible en http:// www.cancer.gov/espanol/tipos/hueso

7. Franchi A. Epidemiology and classification of bone tumors. Clin Cases Miner Bone Metab. 2012;9(2):92-5

8. Niu X, Xu H, Inwards CY, Li Y, Ding Y, Letson D, et.al. Primary Bone Tumors. Epidemiologic Comparison of 9200 Patients Treated at Beijing Ji Shui Tan Hospital, Beijing, China, With 10165 Patients at Mayo Clinic, Rochester, Minnesota. Arch Pathol Lab Med. 2015;139(9):1149-55.

9. Thakur N, Daniels A, Schiller J, Valdes MA, Czerwein JK, Schiller A, et.al. Benign Tumors of the Spine. J Am Acad Orthop Surg. 2012;20(11):715-24.

10. Alpízar-Aguirre A, Rosales-Olivares LM, Sánchez-Bringas G, Zárate-Kalfopulos B, Escutia-García JG, Reyes-Sánchez A. Evaluación de una nueva sistematización de estudios para el diagnóstico de Síndrome de destrucción vertebral. Coluna/Columna. 2012;11(2):151-5.

11. Cai B, Nickman NA, Gaffney DK. The role of palliative external beam radiation therapy in boney metastases pain management. J Pain Palliat Care Pharmacother. 2013;27(1):28-34.

12. Lewandrowski KU, Bell GR, McLain RF. Cancer of the spine: How big is the problem?
En: McLain RF, editor. Cancer in the Spine: Comprehensive Care. Totowa, NJ: Humana Press; 2006. p.1-5.

13. McLain RF, Bell GR. Newer management options in patients with spinal metastasis. Cleve Clin J Med. 1998;65(7):359-66.

14. Constans JP, De Divitiis E, Donzelli R, Spaziante R, Meder JF, Haye C. Spinal metastases with neurological manifestations. Review of 600 cases. J Neurosurg. 1983;59(1):111-8.

15. Abdu WA, Provencher M. Primary bone and metastatic tumors of the cervical spine. Spine (Phila Pa 1976). 1998;23(24):2767-77.

16. Rodríguez-García R, Antonio-Hernández JA, Santiago-Ortíz R, Sosa-Guzmán JJ, Rodríguez-Córdova R, Solis-Daun O. Quiste óseo aneurismático gigante de columna vertebral. Rev Fac Med UNAM. 2003;46(6):218-21.

17. García-Pérez C. Introducción a la seguridad social. En Seguridad Social. Puebla Mex: BUAP -MUM. (consultado 30 Nov. 2013). Disponible en https://garciayperez.wordpress.com/ imss-organos/

18. Gómez-Villanueva A, Chacón-Sánchez J, Santillán-Arreygue L, Sánchez-González Y, Romero-Figueroa M del S. Incidencia de cáncer en una Unidad de Atención Oncológica del Instituto Mexicano del Seguro Social (IMSS), en Toluca, Estado de México. Gac Med Mex 2014:150(4):297-303

19. Kelley SP, Ashford RU, Rao AS, Dickson RA. Primary bone Tumours of the spine: a 42-year survey from the Leeds Regional Bone Tumor Regitry. Eur Spine J. 2007;16(3):405-9.

20. México. Secretaría de Salud. Perfil epidemiológico de los tumores malignos en México: Registro Histopatológico de Neoplasias Malignas 2010. México: Secretaría de Salud: 2011 (consultado 4 Dic. 2013). Disponible en http://www.epidemiologia.salud.gob. mx/doctos/infoepid/publicaciones/2011/monografias/P EPI DE LOS TUMORES MALIGNOS_M\%C3\%A9xico.pdf

21. Benlloch AM, Morales-Codina AM, Bolos-Ten L, Muñoz-Donat S, Valverde-Belda D, Aguirre -García R, et. al. Metástasis vertebrales. Rev Esp Cir Osteoar. 2014;49(257):17-26.

22. Conte G, Gastón-Figueroa M, Lois W, Cabrera CME, León RA, García LH, et. al. Mieloma múltiple en Chile. Características clínicas y sobrevida. Rev Med Chile. 2007;135(9):1111-7. 